\title{
Holocene environmental dynamics in coastal, eastern and central Amazonia and the role of the Atlantic sea-level change
}

\section{Hermann Behling, Göttingen}

\section{Introduction}

The Amazon river system occupies a 7,900,000 $\mathrm{km}^{2}$ drainage area which is larger than Europe. Because of its huge area, Amazonia plays a significant role in the establishment of global climate, water and carbon budget (e.g. SAINT-PAul et al. 1999). Amazonia is mostly covered by rainforest and some savanna ecosystems. The Amazon Basin is low lying with $>1,000,000 \mathrm{~km}^{2}$ at $<100 \mathrm{~m}$ elevation. For much of its course, the Amazon has a grade of 1 in 100,000. The water level in Manaus, which lies $1200 \mathrm{~km}$ inland is only $14 \mathrm{~m}$ a.s.l. (GRABERT 1991). As a consequence, in the eastern half of the basin the development of rivers and lakes is strongly influenced by Atlantic sea-level fluctuations. The amount of annual rainfall as well as the sea-level dynamics influence the occurrence of seasonally inundated forests, which form an area of up to $700,000 \mathrm{~km}^{2}$ (PAVIA 1995). Also Amazonian coastal ecosystems such as mangroves and salt marshes are a result of sea-level fluctuations.

In order to understand past environmental changes in Amazonia such as the natural amplitude of Amazonian ecosystem dynamics, including coastal ecosystems such as mangroves, as well as Amazonian river and climate changes, palaeoecological and palaeoenvironmental studies are important. Several lacustrine and mangrove sediment deposits have been studied by pollen analysis. The aim of this paper is to compare and summarise recently published pollen records and to give an overview of natural environmental changes in the coastal and Amazon Basin region, related to the impact of the Holocene sealevel changes. Tectonic movements/subsidence may have played a certain role as well, but will be not considered in this study.

\section{Vegetation and climate}

The Amazon coastal region includes areas of mangrove, salt marshes, restinga (coastal herb and shrub vegetation), and coastal savanna vegetation (e.g. Bastos 1988; SAntos \& Rosário 1988). Major vegetation types of the Amazon Basin are unflooded upland forests, the so-called terra firme forests, and the seasonally inundated forests, the so-called várzea (white water) and igapó (black water) forests. Furthermore, smaller areas of floodplain herbaceous vegetation and floating meadows may be found. Climatic savannas occur north and south of the Amazon rainforest, while edaphic savanna, (e.g. white sand vegetation), are found within the Amazon rainforest region. General descriptions of central Amazon vegetation have been published by e.g. Ferreira et al. (1997), Hueck (1966), Junk (1970), Junk \& Piedade (1994), Klinge (1973), Klinge et al. (1995), Lisboa et al. (1997), Pires \& Prance (1985), and Prance (1990).

The atmospheric circulation of the Amazon region is controlled by the position of the Intertropical Convergence Zone (ITCZ), shifting from $7-9^{\circ} \mathrm{N}$ in July to $10-20^{\circ} \mathrm{S}$ in January. Consequently two main climate types are represented in Amazonia: a climate without dry season at equatorial latitudes, and a climate with a marked dry season north and south of the equatorial latitudes. South America north of the equator is influenced by the northeasterly trade winds blowing from the Caribbean, whereas the region south of the equator is influenced by the Atlantic southeasterlies, which originate from the subtropical high pressure cell over the south Atlantic Ocean. For most of the Amazon regions the annual precipitation ranges between 1750 and $3500 \mathrm{~mm}$, and the average annual temperature is between 20 and $26{ }^{\circ} \mathrm{C}$ (NIMER 1989; SNOW 1976; WeIschet 1996). The Amazon coastal region receives between 2000 and over $3250 \mathrm{~mm}$ precipitation per year. The climate station of Belém documents a mean annual precipitation of $2277 \mathrm{~mm}$ (WALTER \& LiETH 1967). The average annual temperature is $25.9{ }^{\circ} \mathrm{C}$. Measured maximum and minimum temperatures are $31.7^{\circ} \mathrm{C}$ and $18.0^{\circ} \mathrm{C}$, respectively.

\section{Sites used in the comparison}

For the Amazon lowland regions only a few pollen records are available, reflecting the impact of Holocene sea-level changes (Fig. 1). For the coastal region of Amazonia there is Lagoa da Curuça (BEHLING 1996 , 2001), Lago Crispim (Behling \& Costa 2001), three records from the Braganca Peninsula and Lago Aquiri (Behling \& Costa 1997). For the Amazon Basin region there is Rio Curuá (Behling \& Costa 2000; Costa et al. 1997) and Lago Calado (BeHLing et al. 2001).

Lagoa da Curuça $\left(0^{\circ} 46^{\circ} \mathrm{S}, 47^{\circ} 51^{\circ} \mathrm{W}\right)$ is found in the coastal region of northeastern Pára State, about 


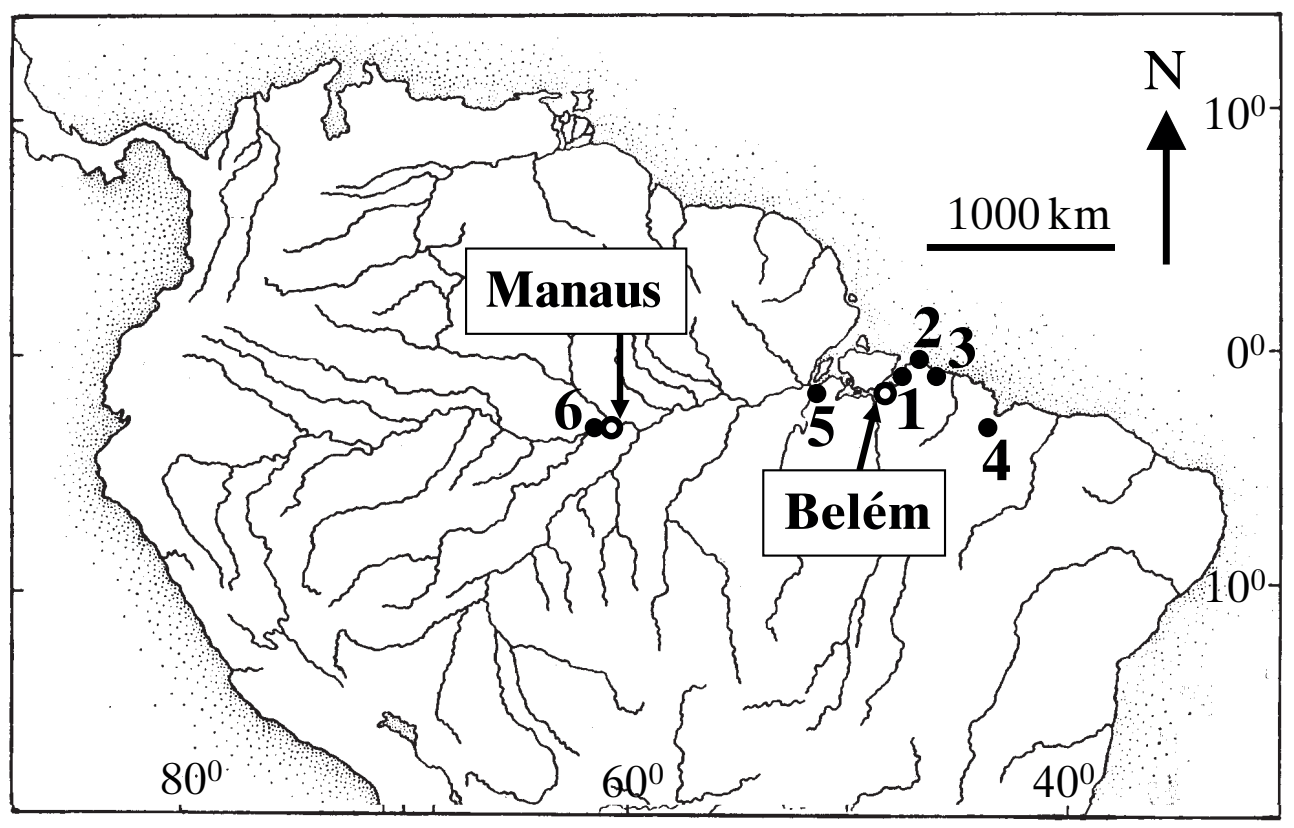

Fig. 1: Map showing the Amazon river system in the coastal region of Amazonia and the location of research sites mentioned in the text: (1) Lagoa da Curuca, (2) Lago Crispim, three records from the (3) Braganca Peninsula, (4) Lago Aquiri, and for the Amazon Basin region: (5) Rio Curuá and (6) Lago Calado

Karte des Amazonas-Entwässerungssystems mit Lage der Untersuchungsgebiete in der Küstenregion: (1) Lagoa da Curuca, (2) Lago Crispim, drei Profile von der Braganca-Halbinsel (3) und Lago Aquiri (4); aus dem Amazonas-Becken: (5) Rio Curuá und (6) Lago Calado

Carte montrant le système fluvial de l'Amazone et la localisation des sites sur la région côtière de l'Amazonie: (1) Lagoa da Curuca, (2) Lago Crispim, trois sites de la (3) Péninsule de Braganca, (4) Lago Aquiri, et sur le bassin amazonien: (5) Rio Curuá et (6) Lago Calado

Cartography: H. BEHLING

$100 \mathrm{~km}$ northeast of the city of Belém in northern Brazil (Fig. 1). The lake is circular shaped, covers an area of ca. 15 hectares and is mostly about $2 \mathrm{~m}$ deep. Lagoa da Curuça is isolated from rivers and lies in a relatively plain landscape at $35 \mathrm{~m}$ elevation, covered with mostly secondary Amazon rainforest vegetation. The lake is about $15 \mathrm{~km}$ from the Atlantic Ocean, but mangrove vegetation grows along small rivers within a distant of about $1.5 \mathrm{~km}$ to the lake.

Lago Crispim $\left(0^{\circ} 46^{\circ} \mathrm{S}, 47^{\circ} 51^{\prime} \mathrm{W}\right)$ also lies in the coastal region of northeastern Pará, about $130 \mathrm{~km}$ northeast of Belém (Fig. 1). The lake is located near the village Crispim, at the west side of the Baiá do Maruda, which is formed by the Rio Marapanim. The isolated lake is 1-2 $\mathrm{m}$ above sea-level and only $500 \mathrm{~m}$ from the modern shore of the bay. The more or less circular lake has a diameter of about $100 \mathrm{~m}$ and a water depth of about $1 \mathrm{~m}$. The lake seems to be part of a former inter-dune valley or channel in a relatively flat coastal area. Modern vegetation near the lake includes coastal vegetation (mangrove, restinga) and, further inland, strongly disturbed Amazon rainforest and edaphic white sand vegetation.

Bragança Peninsula is located between the mouth of the rivers Maiaú and Caeté in the coastal region of northeastern Pará (Fig.1). The area is near Bragança City, about $200 \mathrm{~km}$ east of Belém. The $30 \mathrm{~km}$ long and up to $15 \mathrm{~km}$ wide peninsula is mostly covered by mangroves. Pollen records are available from three different areas. The first site, Bosque de Avicennia $\left(00^{\circ} 55^{\circ} 65^{\prime \prime} \mathrm{S}, 46^{\circ} 40^{\circ} 09^{\prime \prime} \mathrm{W}, 2.4 \mathrm{~m}\right.$ a.s.l $)$, is located on the relatively high central southern part of the peninsula. Only Avicennia trees make up the mangrove forest here. The second site, Campo Salgado (00 $54^{\circ} 46^{\prime \prime}$ S, $46^{\circ} 40^{\circ} 63^{\prime \prime} \mathrm{W}, 2.7 \mathrm{~m}$ a.s.l), is in Cyperaceae-dominated open salt marsh of the central part of the peninsula. The third site, Furo do Chato $\left(00^{\circ} 52^{`} 25^{\prime \prime}\right.$ S, $46^{\circ} 39^{`} 00$, 
$1.9 \mathrm{~m}$ a.s.1), is in the northern part of the study area at a lower elevation than the two other sites. Here Rhizophora trees dominate the mangrove, but Avicennia trees occur close to the site.

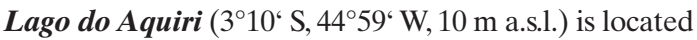
$3 \mathrm{~km}$ north from the village Viana, about $120 \mathrm{~km}$ southwest of São Luis, capital of Maranhão State, and $450 \mathrm{~km}$ southeast of Belém (Fig. 1). The lake lies in a soft rolling landscape with elevated areas between 20-40 m a.s.l. and flood plain areas between 3-10 $\mathrm{m}$ a.s.1.. To the west, the study area is influenced by the river systems of the Rio Mearim. The shortest distance between Lago do Aquiri and Rio Mearim is $20 \mathrm{~km}$, but sometimes a connection forms during the rainy season. During the wet season the fresh water lake is about $11 \mathrm{~km}$ long by $1-3 \mathrm{~km}$ wide, while the water depth is $3 \mathrm{~m}$. During the dry season the lake contracts to a small basin $1-2 \mathrm{~km}$ in diameter. The present-day vegetation to the west of the lake is anthropogenic palm forest/savanna. Mangroves were not observed in the Lago do Aquiri region.

Rio Curuá $\left(1^{\circ} 44^{\circ} 07^{\prime \prime} \mathrm{S}, 51^{\circ} 27^{`} 47^{\prime \prime} \mathrm{W}\right)$ is an inactive river within the Caxiuanã National Forest Reserve, located $350 \mathrm{~km}$ west of Belém (Pará State) in eastern Amazonia (Fig. 1). The surrounding area is relatively flat, only a few meters above sea-level, and covered with Amazonian rainforest. Rio Curuá is connected to the Baía de Caxiuanã which is about $40 \mathrm{~km}$ long and $8-15 \mathrm{~km}$ wide. Water of the inland bay flows about $400 \mathrm{~km}$ to the Atlantic Ocean. Baía de Caxiuanã is mostly shallow, with water depths between 2 and $5 \mathrm{~m}$. The water level is $<3 \mathrm{~m}$ above sea-level. Thus, the Rio Curuá is a low energy river controlled by the amount of water in the Baía de Caxiuanã.

Lago Calado $\left(3^{\circ} 16^{\circ} \mathrm{S}, 60^{\circ} 35^{\circ} \mathrm{W}, 23 \mathrm{~m}\right.$ a.s.l.) is located on the northern bank of the Rio Solimões near the village Manacapuru, about $80 \mathrm{~km}$ upstream from the confluence of the Rio Negro and the Rio Solimões (Fig. 1). The terra firme lake has an outflow to the Rio Solimões that connects the water bodies during times of high water levels. A network of small rainforest streams from the Amazon terra firme forest flow into the lake. Controlled by the Solimões water level, the water depth of the lake fluctuates on an annual cycle between about $1-2 \mathrm{~m}$ in November and roughly $12 \mathrm{~m}$ in June. During the same period the lake surface area changes from 2 to $8 \mathrm{~km}^{2}$. Today várzea/igapó forests cover about $5-10 \%$ of the total forest area of the Lago Calado region.

\section{Holocene environmental changes}

\subsection{Coastal region of Amazonia}

Vegetational changes which reflect sea-level fluctuations are evident in pollen records from the coastal region of northern Brazil. In the Lagoa da Curuça sediment core, Rhizophora pollen grains were already present during the Lateglacial/Holocene transition. These pollen grains were probably transported by wind over some distance into the lake. Mangrove apparently developed along the rivers near the lake between 8080 and 6380 calibrated radiocarbon years before present (cal BP). The subsequent retreat of mangroves from these rivers reflects lower relative sea-level stands between ca. 6380 and 3320 cal BP. Mangrove was replaced by successional stages of palms, first Mauritia, then Arecaceae II and Mauritiella, suggesting a somewhat lower groundwater table in the Lagoa da Curuça area. Mangrove expanded again along the rivers near the lake after 3350 cal BP, indicating the return of relatively high relative sea-levels.

Based on the Lago do Crispim record, mangroves first developed along the river close to the core site between 8370 and $7520 \mathrm{cal}$ BP. There is evidence that areas, originally covered by dense, tall coastal Amazon rainforest, were partly replaced by mangrove and some restinga vegetation during the early Holocene. Decreasing Rhizophora pollen abundances document a retreat of mangroves, reflecting sea-level regression starting at around $7850 \mathrm{cal} \mathrm{BP}$. The marked reduction of mangroves near the lake indicates a lower relative sea-level between around 7520 and $3960 \mathrm{cal}$ BP. During this period a local Mauritia/Mauritiella palm swamp formed. That palm trees are sensitive to the local ground table changes is well known (HENDERson 1995). Marked coastal environmental changes occurred at around 3960 cal BP driven by sea-level transgression. Mangroves expanded again close to the site. The local palm swamp was replaced by a Cype-raceae swamp. Rainforest and restinga vegetation adjacent to the swamp were replaced by salt marshes as sea-level rose. The Atlantic Ocean was close to the core site, but the site, which is only 1-2 $\mathrm{m}$ above modern sea-level, was apparently neveraffected by marine incursions during the Holocene. Reduced mangrove vegetation since ca. 1780 cal BP may be due to a slightly lower relative sealevel or to human impact due to higher occurrence of fire (BEHLING \& Costa 2001).

The Lago Aquiri record, far inland from the modern ocean, shows the formation of mangrove between 8280 and 7570 cal BP. Due to a sedimentary gap, only the last century is recorded. For this period pollen data indicate the present-day environment, seasonally inundated swamp savanna and secondary forests on somewhat higher elevated areas. Mangroves were not found.

Sea-level changes also play an important role in the development and dynamic of mangrove ecosystems on the Bragança Peninsula. The radiocarbon dates 
indicate that the development of mangroves started at the three sites at different times: Campo Salgado at around $5850 \mathrm{cal} \mathrm{BP}$, Bosque de Avicennia at $2210 \mathrm{cal}$ BP and Furo do Chato at 1340 cal BP. The development of mangrove during the early Holocene, as documented from the other sites, is so far not registered on the peninsula.

The presence of mangrove at Campo Salgado, the highest elevated site on the peninsula which today is a salt marsh, suggests relatively high sea-levels since the mid-Holocene. The highest amount of non-mangrove shrub and tree pollen in the basal samples, suggests that mangroves here also replaced an earlier coastal forest ecosystem prior to $5850 \mathrm{cal} \mathrm{BP}$. Compared with other sites from northern Brazil, it is suggested that the relative sea-level during the mid-Holocene was only slightly higher than today. Results from the site Lago do Crispim, which is located next to the modern coastline and only 1-2 $\mathrm{m}$ a.s.l., indicate that it was never flooded during the Holocene (BEHLING \& Costa 2001). Poor pollen preservation between 700 and 450 cal BP, indicate that mangrove deposits were exposed and the area of the Campo Salgado site was relatively dry. The frequency of inundation must have been lower in response to lower sea-levels. Pollen assemblages indicate that an open Poaceae-dominated salt marsh with Avicennia shrubs developed after $450 \mathrm{cal}$ BP. The change from a Poaceae- to a Cyperaceae-dominated modern salt marsh during the last $160 \mathrm{cal} \mathrm{BP}$, may be related to a lower relative sea-level. The high Avicennia pollen concentrations in the sediments from Bosque de Avicennia during the last $150 \mathrm{cal} \mathrm{BP}$, also suggest a regression of sea-level. Studies by CoHEN et al. (2005), show that there has been a recent relative sea-level rise on the Bragança Peninsula during the last three decades.

\subsection{Eastern and central region of Amazon lowland} Sedimentological data from the Rio Curuá core in the Caxiuanã region of eastern Amazonia show that the relatively high energy river changed to a low energy river at ca. $8900 \mathrm{cal} \mathrm{BP}$. The period prior to $7880 \mathrm{cal} \mathrm{BP}$ was characterised by the transition to a passive fluvial (lake-like) system. A well-drained highly diverse terra firme Amazon rainforest was found at that time. Later, a Mauritia palm-swamp developed along the margins of the river between 7880 and $6810 \mathrm{cal} \mathrm{BP}$. The area of inundated várzea and igapó forest along rivers were at that time relatively small. Subsequently, the river changed to shallow lake-like conditions. Abundant terra firme rainforest still occupied the well-drained areas. At $3340 \mathrm{cal}$ BP, the increase of Virola, Euterpe/ Geonoma and Macrolobium, trees which are common in inundated forests (FerreIra et al. 1997), suggest a first expansion of inundated várzea and igapó forest area. After about $2560 \mathrm{cal} \mathrm{BP}$, the pollen data reflect the largest extension of seasonally inundated forests and Rio Curuá reached a water level similar to that of present.

Sedimentological data indicate that the deposits of the core base from Lago Calado in central Amazonia correspond to a fluviatile palaeoenvironment in the Lago Calado valley prior to $9290 \mathrm{cal}$ BP. Pollen analytical results show the formation of a local Mauritia palmswamp along the river margin between 9290 and 8490 cal BP. At that time, highly diverse terra firme Amazon rainforest and poorly developed várzea/igapó forests along the river characterised the vegetation of the study region. The small expansion of várzea/igapó forests and a strong presence of aquatic plants started at $8490 \mathrm{cal} \mathrm{BP}$, reflecting the increase of the Amazonian water level and the formation of the Lago Calado. The occurrence of abundant Poaceae and Cyperaceae pollen in the lake sediments since $8490 \mathrm{cal} \mathrm{BP}$, suggest both the local colonisation of unflooded mud banks around the lake margin and the formation of flooding meadows. Open exposed unflooded mud areas, periodically colonised by herbs, are related to cyclic annual Amazonian high and low water stands. In respect to the abundance of Poaceae pollen during the early and mid-Holocene, these open areas were large, suggesting short annual high and long annual low Amazonian water stands. After 4610 cal BP the area of várzea/igapó forests increased. Herbs were less frequent, probably due to the smaller area of unflooded mud banks. The Amazonian water levels must have been higher than before and the period of the annual high water stands was probably longer. Since $2060 \mathrm{cal} \mathrm{BP}$, the largest proportion of várzea/igapo forests is recorded, reflecting the highest Amazonian water level. Herbs were rare, suggesting that open unflooded mud areas around the lake were relatively small. This may perhaps also indicate that the cyclic annual period of the Amazonian high water level was the longest since $2060 \mathrm{cal}$ BP.

\section{Discussion and conclusions}

During the Last Glacial Maximum (around 21,000 cal $\mathrm{BP}$ ), the Atlantic sea-level was around $120 \mathrm{~m}$ lower than today (e.g. Shackleton \& Opdyke 1973). During the Lateglacial/early Holocene sea-level rise, huge areas of the exposed coastal shelf were inundated by the Atlantic Ocean. The exposed area along the north Brazilian coast was a belt mostly about $150-200 \mathrm{~km}$ wide. Nothing is known about these former ecosystems, but this zone could have been partly covered by Amazon rainforest, savanna, mangrove and other coastal vegetation types.

The compared and summarised pollen record from the Amazon coastal and basin region document 


\section{Vegetation changes in coastal and lowland Amazonia}

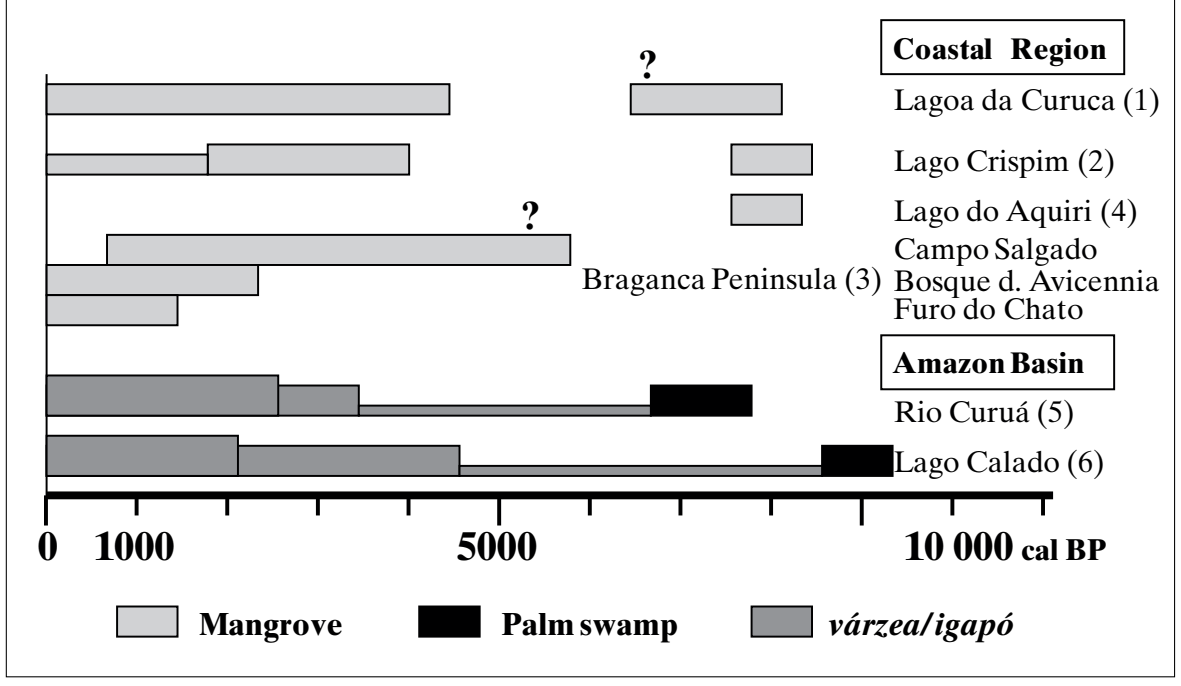

Fig. 2: Graph summarising vegetational changes in the coastal and Amazon lowland region related to Holocene sea-level changes

Zusammenstellung der Vegetationsveränderungen an der Küste und im Innern des Amazonasgebietes im Zusammenhang mit holozänen Meeresspiegelschwankungen

Graphique synthétisant les changements de la végétation de la région côtière et des basses terres de l'Amazonie en relation avec les changements du niveau marin

Graphics: H. BEHLING

remarkable vegetational and environmental changes, related to the Atlantic sea-level rise during the Holocene (Fig. 2, Table 1). The coastline shifted inland during the Lateglacial/early Holocene sea-level rise. Ancient low elevated coastal ecosystems were destroyed and new ecosystems, such as mangroves developed on intertidal, now higher elevated areas, replacing the former Amazon rainforest. First occurrence of mangrove pollen (Rhizophora) in the sediment deposits reflects the early Holocene sea-level rise close to the modern sea-level. Mangrove developed near Lagoa da Curuça between 8080 and 6380 cal BP, at Lago do Aquiri between 8280 and 7570 cal BP and near Lago Crispim between 8370 and 7520 cal BP. The occurrence of some Rhizophora pollen grains in the Lagoa da Curuça record, already at the beginning of the Holocene (at 10660 cal BP or earlier), is probably related to wind transported pollen over somewhat longer distances. Evidence of a mangrove environment in the Aquiri region, about $120 \mathrm{~km}$ inland from the modern coastline, suggests a significant early Holocene transgression near the Rio Mearim.
Due to the very low elevational gradient of the central and eastern Amazonian rivers, the levels of the Amazonian water depend also on Atlantic sea-level. During last glacial low sea-level stages, when the sea-level was over $100 \mathrm{~m}$ lower than today, the gradient was steeper resulting in erosional processes in the Amazon Basin. The Amazon and its tributaries incised and the riverbeds were several tens of meters deeper than today (IrION 1982, 1984; IrION et al. 1995, 1997; Sioli 1957). With the post-glacial rise of the Atlantic sea-level, the waters in the Amazon Basin rose as well.

The influence of the early Holocene sea-level rise in the Amazon Basin is found by the change of active high erosive to a passive river (lake-like) system of the Rio Curuá record in eastern Amazonia and of the Lago Calado record in central Amazonia at ca. 8900 and at $9290 \mathrm{cal} \mathrm{BP}$, respectively. These events occurred about 500-1000 years earlier than the first mangrove formation near the modern coastline. In both records a local Mauritia palm swamp stage is found, in Rio Curuá in eastern Amazonia between 7880 and $6810 \mathrm{cal}$ $\mathrm{BP}$ and in Lago Calado in central Amazonia between 


\begin{tabular}{|l|l|l|l|l|l|}
\hline $\begin{array}{l}\text { First event/ } \\
\text { site }\end{array}$ & $\begin{array}{l}\text { Modern } \\
\text { elevation }\end{array}$ & $\begin{array}{l}\text { Vegetational } \\
\text { change to }\end{array}$ & $\begin{array}{l}\text { Past elevation } \\
\text { (m a.s.l.) }\end{array}$ & $\begin{array}{l}\text { Period } \\
\text { (cal BP) }\end{array}$ & $\begin{array}{l}\text { Length } \\
\text { (yr) }\end{array}$ \\
\hline Lagoa da Curuça & $35 \mathrm{~m}$ & Mangrove & $32 \mathrm{~m}$ & $8080-6380(?)$ & $1700(?)$ \\
\hline Lago Crispim & $1-2 \mathrm{~m}$ & Mangrove & $-6 \mathrm{~m}$ & $8370-7520$ & 850 \\
\hline Lago do Aquiri & ca. $10 \mathrm{~m}$ & Mangrove & ca. $1.5-7 \mathrm{~m}$ & $8280-7570$ & 710 \\
\hline Rio Curuá & $<3 \mathrm{~m}$ & Mauritia-swamp & $-11 \mathrm{~m}$ & $7880-6810$ & 1070 \\
\hline Lago Calado & $23 \mathrm{~m}$ & Mauritia-swamp & ca. $5 \mathrm{~m}$ & $9290-8490$ & 800 \\
\hline
\end{tabular}

\begin{tabular}{|c|c|c|c|c|c|}
\hline $\begin{array}{l}\text { Second event/ } \\
\text { site }\end{array}$ & $\begin{array}{l}\text { Modern } \\
\text { elevation }\end{array}$ & $\begin{array}{l}\text { Vegetational } \\
\text { change to }\end{array}$ & $\begin{array}{l}\text { Past elevation } \\
\text { (m a.s.l) }\end{array}$ & \begin{tabular}{|l|} 
Period \\
(cal BP)
\end{tabular} & \begin{tabular}{|l|}
$\begin{array}{l}\text { Length } \\
\text { (yr) }\end{array}$ \\
\end{tabular} \\
\hline Lagoa da Curuça & $35 \mathrm{~m}$ & Mangrove & $32.5 \mathrm{~m}$ & ca. 4410- 0 & 4410 \\
\hline Lago Crispim & $1-2 \mathrm{~m}$ & Mangrove & $-1--0.75 \mathrm{~m}$ & $3960-1780$ & 2180 \\
\hline $\begin{array}{l}\text { Bragança Peninsula } \\
\text { Campo Salgado } \\
\text { Bosque d. Avicennia } \\
\text { Furo do Chato }\end{array}$ & $\begin{array}{l}2.7 \mathrm{~m} \\
2.4 \mathrm{~m} \\
1.9 \mathrm{~m}\end{array}$ & $\begin{array}{l}\text { Mangrove } \\
\text { Mangrove } \\
\text { Mangrove }\end{array}$ & $\begin{array}{l}1.35 \mathrm{~m} \\
-4.0 \mathrm{~m} \\
0.1 \mathrm{~m}\end{array}$ & $\begin{array}{l}5850(?)-700 \\
2210-0 \\
1340-0\end{array}$ & $\begin{array}{l}5150(?) \\
2210 \\
1340\end{array}$ \\
\hline Rio Curuá & $<3 \mathrm{~m}$ & >várzea/igapó & $(-5 m)-4.5 m$ & $3340 / 2560-0$ & 3340 \\
\hline Lago Calado & $23 \mathrm{~m}$ & >várzea/igapó & ca. $10 / 12.5 \mathrm{~m}$ & $4610 / 2060-0$ & 4610 \\
\hline
\end{tabular}

Tab. 1: List of the summarised and compared pollen records highlighting two major events of environmental changes. The table includes data on the current elevation ( $\mathrm{m}$ above mean modern sea-level) of the coring site, as well as elevation values at the time of the environmental changes.

Liste der verglichenen Pollenprofile mit Altersstellung zweier besonderer Phasen der Umweltveränderungen. In der Tabelle sind auch die Angaben zur heutigen und vorzeitlichen Meereshöhe ( $m$ ü.M.) an den Standorten dargestellt.

Liste synthétique et comparative des relevés polliniques montrant les deux principaux changements environnementaux. Le tableau présente l'altitude du site de carottage (m au-dessus du niveau moyen marin actuel) et les altitudes durant les changements environnementaux.

9290 and $8490 \mathrm{cal} \mathrm{BP}$. The timing and length of this successional period differs, which may be related to the different location and topography of the two rivers. These palm swamp stages occurred before or during the period of the mangrove development in coastal Amazonia. It is supposed that the Mauritia palmswamp stage is a regional phenomenon for low-lying areas in the Amazon Basin, related to the sea-level rise during the early Holocene. First várzea and igapó forests developed at that time as well, but the area of seasonally inundated forests was small.

In the coastal region a retreat of the mangroves is found, reflecting a lower relative sea-level: in Aquiri since $7770 \mathrm{cal} \mathrm{BP}$, in Lago Crispim between 7520 and $3960 \mathrm{cal} \mathrm{BP}$ and in Lagoa da Curuça between about 6380 and $4410 \mathrm{cal} \mathrm{BP}$. The interpolated age of $6380 \mathrm{cal}$ $\mathrm{BP}$ for the Lagoa record can be older, due to the poor radiocarbon dating of the core. During this mid-Holocene sea-level regression, in lowland Amazonia shallower water levels than today are recorded, between 6810 and $3340 \mathrm{cal}$ BP in Rio Curuá and between 8490 and 4610 cal BP in Lago Calado.

The second major period of mangrove formation at the modern coastline occurred during the late Holocene, at the Lagoa da Curuça record since around $4410 \mathrm{cal}$ $\mathrm{BP}$ and at the Lago Crispim record since $3960 \mathrm{cal} \mathrm{BP}$, reflecting the highest Holocene sea-level stands. The first development of mangroves on the Bragança Peninsula is found in the Campo Salgado area at around $5850 \mathrm{cal}$ BP. It is suggested that the radiocarbon date form the Campo Salgado core base is too old in comparison with events of the Lago do Crispim, Lagoa da Curuça and the two Amazon Basin record. The beginning of the mangrove development at the Campo Salgado site is probably not older than $4500 \mathrm{cal} \mathrm{BP}$. The formation of mangroves at the Bosque de Avicennia site started at around $2210 \mathrm{cal} \mathrm{BP}$ and at the Furo do Chato since around $1340 \mathrm{cal} \mathrm{BP}$.

In the eastern Amazon Basin a marked increase of várzea/igapó forests is documented in the Rio Curuá record since $3340 \mathrm{cal} \mathrm{BP}$ and especially since $2560 \mathrm{cal}$ BP. In the central Amazonia a marked increase of seasonally inundated forest is found since $4610 \mathrm{cal} \mathrm{BP}$ and especially since $2060 \mathrm{cal} \mathrm{BP}$. The marked increase of inundated areas of várzea/igapó forests is apparently related to the late Holocene sea-level rise and almost the complete low lying Amazon Basin seem to have experienced this change. Huge areas of terra firme Amazon rainforest were replaced by várzea and igapó 
forests during the late Holocene. The development of large seasonally inundated areas must have had an important influence on the Amazonian water and carbon cycle and the regional climate in Amazonia.

The development and the modern extension of mangrove forests in the Amazon coastal region and the large extended areas of modern seasonally inundated várzea/igapó forests in the lower Amazon Basin, consequently, are relatively young in age.

The Atlantic sea-level rise was probably the major factor in palaeoenvironmental changes, but high water stands might also partly be related to climate change involving greater annual rainfall rates in Amazonia and in the Andes. There is evidence of Amazon rain forest expansion, both north and south of the equator, reflecting a change to wetter climatic conditions (higher precipitation rates and longer wet periods) since mid and especially during the late Holocene (BeHLing \& HooghiEmSTRA 2001; Behling et al. 2010). In the northwestern Amazon rainforest/savanna transition zone (Llanos Orientales in Colombia) rainforest expansion is documented since $6850 \mathrm{cal} \mathrm{BP}$ and was further intensified after 3200 cal BP (Behling \& Hooghiemstra 2000). In southwestern Amazonia, there is evidence of Amazon rain forest expansion (Laguna Bella Vista and Chaplin, Bolivia) during the late Holocene at least since $3200 \mathrm{cal}$ BP (MaYle 2011; Mayle et al. 2000). The expansion of the Amazon rain forest after $6260 \mathrm{cal} \mathrm{BP}$ is also reported for the southeastern Amazon region (BEHLING 2002).

In western Amazonia (Colombia) the lower terrace of Rio Caquetá was poorly drained after $4480 \mathrm{cal} \mathrm{BP}$, as a result of higher river levels, probably due to higher precipitation rates (BEHLING et al. 1999). In this context in the Lago Calado record, possibly relatively short annual high water levels during the early Holocene and relatively long annual high water levels since 4610 and especially after $2060 \mathrm{cal} \mathrm{BP}$, can be interpreted as indicators of climate change to wetter late Holocene periods (BeHLing et al. 2001). Somewhat cooler climatic conditions and therefore decreasing evaporation may also have played a certain role.

Thus, although the Atlantic sea-level rise was probably the major factor in palaeoenvironmental changes, high water stands might also be due to greater annual rainfall during the late Holocene in western, central and eastern Amazonia.

\section{References}

BASTOS, M. DE N. Do C. (1988): Levantamento florístico em restinga arenosa litorânea na Ilha de MaiandeuaPará. - In: Boletim do Museu Paraense Emílio Goeldi, Nova Série Botânica 4, 1:159-173.
Behling, H. (1996): First report on new evidence for the occurrence of Podocarpus and possible human presence at the mouth of the Amazon during the Lateglacial. - In: Vegetation History and Archaeobotany 5, 3: 241-246.

Behling, H. (2001): Late Quaternary environmental changes in the Lagoa da Curuca region (eastern Amazonia) and evidence of Podocarpus in the Amazon lowland. - In: Vegetation History and Archaeobotany 10, 3:175-183.

Behling, H. (2002): Late Quaternary vegetation and climate dynamics in southeastern Amazonia inferred from Lagoa da Confusão in Tocantins State, northern Brazil. - In: Amazoniana 17, 1-2:27-39.

Behling, H. \& M.L. Costa (1997): Studies on Holocene tropical vegetation, mangrove and coast environments in the state of Maranhão, NE Brazil. - In: Quaternary of South America and Antarctic Peninsula 10, 7: 93-118.

Behling, H. \& M.L. Costa (2000): Holocene environmental changes from the Rio Curuá record in the Caxiuanã region, eastern Amazon Basin. - In: Quaternary Research 53, 3:369-377.

Behling, H. \& M.L. Costa (2001): Holocene vegetational and coastal environmental changes from the Lago Crispim record in northeastern Pará State, eastern Amazonia. - In: Review of Palaeobotany and Palynology 114, 3-4: 145-155.

Behling, H. \& H. Hooghiemstra (2000): Holocene Amazon rain forest - savanna dynamics and climatic implications: high resolution pollen record from Laguna Loma Linda in eastern Colombia. - In: Journal of Quaternary Science 15, 7: 687-695.

Behling, H. \& H. Hooghiemstra (2001): Neotropical savanna environments in space and time: Late Quaternary interhemispheric comparisons. - In: MARKGRAF, V. (ed.): Interhemispheric climate linkages. - London: Academic Press: 307-323.

Behling, H., Berrio, J.C. \& H. Hooghiemstra (1999): Late Quaternary pollen records from the middle Caquetá river basin in central Colombian Amazon. In: Palaeogeography, Palaeoclimatology, Palaeoecology 145, 1-3: 193-213.

Behling, H., Bush, M.B. \& H. Hooghiemstra (2010): Biotic development of Quaternary Amazonia: a palynological perspective. - In: Hoorn, C. \& F.P. WeSSELINGH (eds): Amazonia: landscape and species evolution. A look into the past. - Oxford: Blackwell: 335345.

Behling, H., Cohen, M.C.L. \& R.J. Lara (2001): Studies on Holocene mangrove ecosystem dynamics of the Bragança Peninsula in northeastern Pará, Brazil. - In: Palaeogeography, Palaeoclimatology, Palaeoecology 167, 3-4: 225-242.

Behling, H., Keim, G., Irion, G., JunK, W. \& J. Nunes DE Mello (2001): Holocene environmental changes in the Central Amazon Basin inferred from Lago Calado 
(Brazil). - In: Palaeogeography, Palaeoclimatology, Palaeoecology 173, 1-2: 87-101.

Cohen, M.C.L, Souza Filho, P.W., Lara, R.J., BehLING, H. \& R. ANGulo (2005): A model of Holocene mangrove development and relative sea-level changes on the Bragança Peninsula (Northern Brazil). - In: Wetlands Ecology and Management 13, 4: 433-443.

Costa, M.L., Moraes, E.L., Behling, H., Melo, J.C.V. \& N.V.M. Siqueria (1997): Os sedimentos de fundo da Baía de Caxiuanã. - In: LisboA, P.L.B. (ed.): Caxiuanã. - Belém: Museu Paraense Emílio Goeldi: 121-137.

Ferreira, L.V., Almeida, S.S. \& C.S. Rosário (1997): As áreas de inundaçao. - In: Lisboa, P.L.B. (ed.): Caxiuanã. - Belém: Museu Paraense Emílio Goeldi: 195-211.

Grabert, H. (1991): Der Amazonas. - Berlin: Springer. Henderson, A. (1995): The palms of the Amazon. New York: Oxford University Press.

Hueck, K. (1966): Die Wälder Südamerikas. - Stuttgart: Fischer.

IRION, G. (1982): Mineralogical and geochemical contribution to climatic history in Central Amazonia during Quaternary times. - In: Tropical Ecology 23: 76-85.

IrION, G. (1984): Clay minerals of Amazonian soils. In: Sioli, H. (ed.): The Amazon. Limnology and landscape of a mighty tropical river and its basins. - Monographiae Biologicae 56, Dordrecht: Junk: 537-579.

Irion, G., Junk, W. \& J. Nunes de Mello (1997): The large Central Amazonian River floodplains near Manaus: geological, climatological, hydrological and geomorphological aspects. - In: JUNK, W. (ed.): The Central Amazon floodplain. - Berlin: Springer: 23-46.

Irion, G., Müller, J., Mello, J.N. De \& W.J. JunK (1995): Quaternary geology of the Amazonian lowland. - In: Geo-Marine Letters 15, 3-4: 172-178.

JUNK, W. (1970): Investigations on the ecology and production-biology of the «Floating Meadows» (Paspalo-Echinochloetum) on the Middle Amazon. - In: Amazoniana 11: 449-495.

Junk, W. \& M.T.F. Piedade (1994): Species diversity and distribution of herbaceous plants in the floodplain of the middle Amazon. - In: Verhandlungen des Internationalen Verein Limnologie 25: 1862-1865.

KLINGE, H. (1973): Struktur und Artenreichtum des zentralamazonischen Regenwaldes. - In: Amazoniana 4:283-292.

Klinge, H., Adis, J. \& M. Worbes (1995): The vegetation of a seasonal várzea forest in the lower Solimões River, Brazilian Amazonia. - In: Acta Amazonica 25, 3-4: 201-220.

Lisboa, P.L.B., Silva, A.S.L. \& S.S. Almeida (1997): Florística e estrutura dos Ambientes. - In: LisBoA, P.L.B. (ed.): Caxiuanã. - Belém: Museu Paraense Emílio Goeldi: 163-193.

Mayle, F. (2011): A review of Holocene rainforest ecotonal dynamics at opposite ends of the Amazon -
Bolivia versus Colombia. - In: Geographica Helvetica 66, 3: 202-207.

Mayle, F., Burbridge, R. \& T.J. Killeen (2000): Millennial-scale dynamics of southern Amazonian rain forests. - In: Science 290, 5500: 2291-2294.

Nimer, E. (1989): Climatologia do Brasil. - Rio de Janeiro: Fundação Instituto Brasileiro de Geografia e Estatística.

Pavia, F. (1995): Der Amazonas. - Köln: Eco.

Pires, J.M. \& G.T. Prance (1985): The vegetation types of the Brazilian Amazon. - In: Prance, G.T. \& LoveJoY, T.E. (eds): Key environments Amazonia. - Oxford: Pergamon Press: 109-145.

Prance, G.T. (1990): The floristic compositon of the forests of Central Amazonian Brazil. - In: GeNTRY, A.H. (ed.): Four neotropical rainforests. - New Haven: Yale University Press: 112-140.

SAInt-Paul, U., SchlÜter, U.-B. \& H. Schmidt (1999): The significance of Amazonian rain forest deforestation for regional and global climate change - a review. - In: Ecotropica 5, 2: 87-114.

SANTos, J.V.M. Dos \& C. DA S. RosárIo (1988): Levantamento da vegetação fixadora das dunas de Algododoal-PA. - In: Boletim do Museu Paraense Emílio Goeldi, Nova Série Botânica 4, 1:133-154.

Shackleton, N.J. \& N.D. Opdyke (1973): Oxygen isotope and paleomagnetic stratigraphy of equatorial Pacific core V28-238: oxygen isotope temperatures and ice volumes on a 105 and 106 year scale. - In: Quaternary Research 3, 1: 39-55.

Sioli, H. (1957): Sedimentation im Amazonasgebiet. In: Geologische Rundschau 45, 3: 608-633.

SNow, J.W. (1976): The climate of northern South America. - In: SchwerdtFeger, W. (ed.): Climates of Central and South America. - World survey of climatology 12, Amsterdam: Elsevier: 295-403.

WALTER, H. \& H. LieTH (1967): Klimadiagramm-Weltatlas. - Jena: Fischer.

Weischet, W. (1996): Regionale Klimatologie. 1. Die Neue Welt. - Stuttgart: Teubner.

\section{Abstract: Holocene environmental dynamics in coastal, eastern and central Amazonia and the role of the Atlantic sea-level change}

Several pollen records from selected sites of coastal, eastern and central Amazonia are summarised and compared to provide insights in Holocene environmental changes. The hydrology of Amazonian wetlands, especially those in the eastern part of the Basin, is strongly influenced by the Atlantic sea-level. Sea-level rise in the early Holocene stabilized at near modern levels at ca. 8300 cal BP (calibrated radiocarbon years before present), reflected by the first occurrence of mangroves at the present-day coastal line. The retreat of mangroves after about $7750 \mathrm{cal} \mathrm{BP}$ reflects a lower relative sea-level. The modern mangroves developed 
mostly about $4500 \mathrm{cal} \mathrm{BP}$ or somewhat later at the present-day coastline. First impact of early Holocene sealevel rise in the Amazon Basin is found by the change of an active to a passive (lake-like) river system about 8900 cal BP. Later, local Mauritia palm swamps developed along river margins in central and eastern Amazonia. This stage is probably a regional phenomenon for the whole low lying Amazon Basin. First várzea and igapó forests (seasonally inundated forests) developed at that time as well, but their size was still small. In eastern and central Amazonia, marked increase of várzea/igapó forests is documented since mid- to late Holocene. The development of huge seasonally inundated areas must have had an important influence on the Amazonian water and carbon cycle and the regional climate in Amazonia.

Keywords: Northern Brazil, environmental history, palynology, palaeoecology, mangrove, Amazon rainforest, várzea, igapó, Holocene, sea-level

\section{Zusammenfassung: Holozäne Umweltveränderungen an der Küste, im östlichen und im zentralen Amazo- nasgebiet und die Bedeutung der Meeresspiegel- schwankungen des Atlantik}

Mehrere Pollenprofile von ausgewählten Standorten an der Küste sowie dem östlichen und zentralen Amazonasgebiet wurden zusammengefasst und verglichen, um bessere Einblicke in die holozänen Umweltveränderungen zu bekommen. Die Hydrologie der amazonischen Feuchtgebiete, besonders die im östlichen Teil des Beckens, sind stark vom Niveau des Atlantischen Meeresspiegels beeinflusst. Der Meeresspiegelanstieg stabilisierte sich um etwa 8300 cal BP (kalibrierte Radiokarbonjahre vor heute) auf ungefähr die heutige Höhenlage, was durch die ersten Mangroven an der heutigen Küstenlinie dokumentiert wird. Der Rückzug der Mangroven nach etwa $7750 \mathrm{cal}$ BP deutet auf einen relativ niedrigen Meeresspiegel hin. Die heutigen Mangroven entwickelten sich überwiegend um $4500 \mathrm{cal} \mathrm{BP}$ oder etwas später an der heutigen Küstenlinie. Der erste Einfluss des frühholozänen Meeresspiegelanstiegs im Amazonasbecken ist erkennbar durch den Wechsel von einem aktiven zu einem passiven (seeähnlichen) Flusssystem um 8900 cal BP. Etwas später entwickelten sich lokal MauritiaPalmensümpfe entlang der Flussläufe im zentralen und östlichen Amazonasgebiet. Dieses Stadium ist offenbar ein regionales Phänomen für das gesamte tief liegende Amazonasbecken. Erste várzea- und igapóWälder (saisonale Überschwemmungswälder) entwikkelten sich auch zu dieser Zeit, aber sie waren flächenmässig noch relativ klein. Die starke Ausbreitung der várzea- und igapó-Wälder ist seit dem mittleren bis späten Holozän dokumentiert. Die Entwicklung der riesigen saisonalen Überschwemmungswälder muss einen bedeutenden Einfluss auf den amazonischen
Wasser- und Kohlenstoffkreislauf und das regionale Klima gehabt haben.

Schlüsselwörter: Nordbrasilien, Umweltgeschichte, Palynologie, Paläoökologie, Mangroven, AmazonasRegenwald, várzea- und igapó-Wälder, Holozän, Meeresspiegel

\section{Résumé: Dynamiques environnementales holocènes en Amazonie côtière, orientale et centrale et rôle du changement du niveau de l'Atlantique}

Plusieurs relevés polliniques d'Amazonie côtière, orientale et centrale sont synthétisés et comparés afin de rendre compte des changements environnementaux holocènes. L'hydrologie des zones humides amazoniennes, en particulier celles de l'est du bassin, est fortement influencée par le niveau de l'Atlantique. L'augmentation du niveau marin s'est stabilisée à ses niveaux actuels à environ $8300 \mathrm{cal} \mathrm{BP}$, mis en évidence par la présence de mangroves sur la côte actuelle. Le retrait des mangroves après environ 7750 cal BP reflète un niveau marin plus bas. Les mangroves modernes se sont développées principalement vers $4500 \mathrm{cal} \mathrm{BP}$ ou peu après sur la ligne côtière actuelle. Le premier impact de la remontée de l'océan dans le bassin amazonien au début de l'Holocène est la transformation d'un système fluvial actif en un système passif vers 8900 cal BP. Plus tard, les marais de palmiers Mauritia se sont développés le long des rivières en Amazonie centrale et orientale. Ce stade est probablement un phénomène régional pour l'ensemble des basses terres du bassin amazonien. Des forêts périodiquement inondées (várzea et igapó) se sont également développées à ce moment-là mais leur taille était réduite. En Amazonie orientale et centrale, un accroissement des forêts de várzea et d'igapó est documenté depuis le milieu de l'Holocène. Le développement d'immenses zones périodiquement inondées doit avoir eu une influence importante sur le cycle de l'eau et du carbone et sur le climat régional de l'Amazonie.

Mots-clés: nord du Brésil, histoire environnementale, palynologie, paléoécologie, mangrove, forêt amazonienne, várzea, igapó, Holocène, niveau marin

Prof. Dr. Hermann Behling, Department of Palynology and Climate Dynamics, Albrecht-von-HallerInstitute for Plant Sciences, University of Göttingen, Untere Karspüle 2, D-37073 Göttingen, Germany. e-mail: Hermann.Behling@bio.uni-goettingen.de

\section{Manuskripteingang/received/manuscrit reçu le} 18.4.2011

Annahme zum Druck/accepted for publication/accepté pour publication: 14.10 .2011 